\title{
Developments in Politeness from Aristophanes to Menander and Beyond
}

\author{
Peter Barrios-Lech
}

\section{1 \\ Introduction: Developments in Politeness from the Fifth to the} Third Centuries BCE

My aim is to describe developments in the polite language of late fifth century BCE Athens, when Aristophanes wrote, to the time when Menander was active (early third century BCE). By 'polite language,' I mean those expressions, routines, and scripts by which a speaker expresses consideration for the other. They are an ubiquitous part of our own daily language use. Polite expressions (in English, 'please'; 'can you + verb'); routines (for instance, facilitating closure to a conversation); and scripts (enabling predictable structure to even the most informal talk); these provide quarry for students of politeness because they demonstrate how people express, negotiate and manage the sometimes unpredictable terrain of face-to-face interaction. And this polite language, so defined, changes over time, just as the language's phonology, morphology, or syntax.

Now, Aristophanes wrote when Athenian democracy was in full bloom. In fifth-century Athens, every citizen enjoyed the right to speak his mind in assembly and he benefitted from legal protections. The reforms of Cleisthenes had succeeded to some extent in eliminating distinctions of wealth or family background as a meaningful basis of political involvement. Any violenceverbal or physical—done to a free Athenian citizen was ü $\beta$ pıs, an actionable offense. Menander wrote when democracy was effectively dead, a Macedonian garrison ensuring order in the polis. Is it possible that the death of democracy produced changes in the polite language of Classical Athens?

Answering such a question might, at first sight, seem challenging. We cannot eavesdrop on the gossip of the fishmonger with his client in the agora of fifth-century Athens; nor hear two Athenians wrangling about the quality of Sophocles' recent production; still less can we question them, like modern-day linguists, about any polite usages peppering their speech. Spontaneous conversation and questionnaires, however, are precisely the forms of evidence used by sociolinguists of modern languages. What evidence do Classicists have available?

We have access to text-genres that capture living voices in conversation (dialogue, drama, epistles). We also have the ancients' comments-often casual, 
obiter dicta - on 'pragmatic' characteristics of certain expressions; for instance, whether the imperative was indeed felt to be rude. Parallels from modern languages are helpful, as long as we do not equate these parallelisms with the ancient phenomena. In doing so we risk 'familiarising' the politeness of the ancients, and so effacing how alien to us that politeness may be.

In fact, we, as students of ancient politeness, are not that badly off compared to our peers who study modern languages. As Michael Lloyd (2004: 75) points out:

Literary dialogue has the advantage of being completely transparent in terms of context. All relevant factors are in principle available for anyone to test. Experimental data, by contrast, are inevitably incomplete and opaque, as well as being subject to distortion by the prejudices of the investigator or the artificial nature of the experiment.

Here we think of the 'Observer's Paradox': that is, we want spontaneously produced speech, but the presence of the observer inevitably elicits the opposite. Labov famously found this when researching how members from various social classes produced a certain phonological variable. He found that members from the working class, when questioned by him, would assume a higher register of speech (Labov 1972: 61, 209). Questionnaires and role-plays are also problematic each in their own way. For instance, the questionnaire-prompt, including description of the real-world context, might influence the respondent's answer; and his or her written response might be more formal than a spoken one (Márquez-Reiter 2000: 73). ${ }^{1}$

So we have texts that imitate dialogue, dialogue which, however artificial compared to spontaneous conversation, allows the observer to isolate all relevant variables: speaker and addressee status, context, both global (genre), and local (specific topic; the surrounding 'co-text'); and the social and historical matrix giving rise to the text. Besides, students of ancient Greek politeness have plenty of data at their disposal: the corpus of Classical Greek-and beyond. We can take a snapshot, say, a synchronic study of ancient Greek politeness in the fifth century $\mathrm{BCE}$, relying mainly on dramatic texts, or we can view the whole from a bird's eye perspective, as we will try to do: taking in developments

1 An example of a questionnaire prompt from Márquez-Reiter (2000: 73) illustrates this: 'You missed a lecture yesterday and would like to borrow the notes from a class mate/ You:

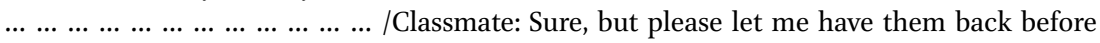
the lecture next week.' Note also that the Classmate's answer-unknowable in an actual conversation-might also condition the response. 
over the course of a century and a half, from the late fifth to the early third centuries BCE in Athens.

In this contribution to the study of ancient Greek 'language of politeness', I focus on one particular category of data, the directive (essentially, commands and requests), drawn from the plays of Aristophanes, Menander, Hellenistic Mime, and one Platonic dialogue (the Cratylus). These authors-Aristophanes, Menander, Herodas (contemporary with Theocritus and mime-writer) and Plato-did not have the same goals that we do, and this is an advantage for us. While theirs was to entertain and edify audiences and readers, they routinely overlook the kinds of linguistic detail that we are interested in: perfunctory salutations, conversation closings and pre-closings, dialogue transition devices, and, of importance for us, routine requests and commands.

Now it is true that some authors-like Menander and Xenophon-were happy to repeat the same formulae over and over again. The repetition of conversational formulae and colloquial expressions is also an advantage for the researcher attempting to recover the polite language of the Athenians. But other authors, like Plato and Homer, aim to vary such expressions. ${ }^{2}$ So our data, it must be said, come from authors disparate in style and in their relation to the spoken idiom.

Can we turn this difference in authorial style to our advantage? To anticipate the description of our corpus, most of our data will come from Aristophanes and Menander. There could not exist two more different playwrights. Plutarch famously wrote on those differences, simultaneously expressing his distaste, if not contempt for Aristophanes. To take an example, Menander suits his language to context; Aristophanes does not, according to Plutarch:

\section{[1] Plutarch Comparison of Aristophanes and Menander 853b5-8}

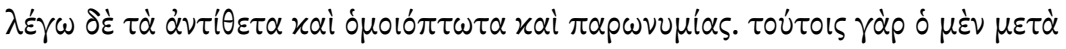

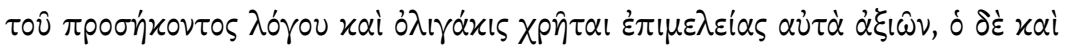

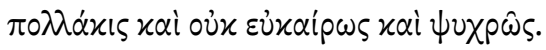

I'm talking about antitheses and successive words with the similar endings; puns. Menander, deeming their usage worth careful attention, employs them in suitable contexts, and infrequently. But Aristophanes uses them frequently, not at the right moment, and insipidly.

2 Dickey (2016a: 247-248). 
And Plutarch distinguishes the comic poets in other ways. ${ }^{3}$ Although Plutarch is, of course, biased, no-one will dispute that these two authors have divergent styles. Each wrote at a different historical moment, under a different regime, and in a different genre. Suppose, then, a pattern shows up in Aristophanes and recurs in Menander; for instance, that the proportion of all imperatives softened in each author is the same. Menander was hardly likely to imitate Aristophanes in this subtle particular. We could argue, instead, that both authors reproduce a speech pattern which had remained stable for over a century. In fact, the statistics calculated from our congeries of Attic authors writing in different genres and at different historical moments suggests a surprising stability in the polite language of the ancient Greek polis, specifically Athens, despite regime changes.

Indeed, Dickey, writing on the Greek imperative, says '[i]n literature there appears to be no change in the way requests are made at any period of antiquity, just as there appears to be no change in Greek grammar or spelling' (Dickey 2016a: 244). This claim is based on the survey of an ample corpus of directives, with particular attention to how requests are framed. ${ }^{4}$ Any continuity in the politeness system of these texts, then, may be due to the conservatism of the authors - with regard to grammar, spelling, and 'pragmatic' features of the language.

Still, even Dickey (2016a: 247) concedes that colloquial language must surface in our Attic texts, with certain authors (Aristophanes, Aeschylus, Plato) avoiding conversational formulae while others (Menander, Xenophon) employ them frequently. Following this line of reasoning, we can view the continuities across these disparate authors as evidence for actual speech habits. Or, if one prefers, the cross-genre regularities of language will be worth documenting, for they can provide comparanda for similar regularities as represented in the texts of other languages, most obviously, Latin; or comparanda for texts in the same language-Greek-but written at different places and times.

For instance, the mimes of Herodas - coeval of Callimachus, and perhaps active in the intellectual circles of Ptolemy II-and the mimes from imperial Rome present patterns strikingly different from those in our Attic corpus,

3 For further contrasts in Plutarch see esp. Plut. Comp. Ar. et Men. 853b5-8 (Menander characterises on the linguistic level, Aristophanes does not); Menander has achieved the remarkable feat of creating a language which gives the impression of uniformity while in fact suiting itself to characters of various kinds: Plut. Comp. Ar. et Men. 853d10-853e4.

4 Dickey (2016a) surveys Homer, Odyssey 1-4; Sophocles, Philoctetes, Antigone; Euripides, Hippolytus, Medea; Aristophanes, Acharnians, Knights; Menander, Dyscolus, Aspis, Epitrepontes; Herodotus (all); Plato, Symposium. 
TABLE 1 Classical and Hellenistic

Greek directive database

Author Directives

\begin{tabular}{lr} 
Aristophanes & 3223 \\
Menander & 830 \\
Mime & 278 \\
Plato (Cratylus) & 139 \\
Total & 4470 \\
\hline
\end{tabular}

although the data culled from these mimes is, unfortunately, limited. Still, that major shifts in the politeness system did happen from the Classical to the Hellenistic period has been attested with the help of other evidence-Hellenisticera letters preserved on papyrus (Dickey 2016a: 247).

I have four sub-corpora, drawn from distinct points in the temporal flow: fifthcentury Old Comedy, represented by Aristophanes, whose language preserves with more or less fidelity a colloquial Attic spoken in the fifth century BCE; Plato, writing in the mid-fourth century $\mathrm{BCE}$, whose language imitates the more learned discourse of an Athenian élite; the early third century Menander, whose plays similarly reflect an Attic, but an every-day idiom, spoken about a century later, and one which was well on its way to becoming the Koine; finally, Hellenistic Mime, whose language also comes close to the colloquial idiom. This latter 'Mime' corpus should be subdivided into two: we have data from the mimes of Herodas and from scripted mimes presumably performed during the Roman imperial period. All of this data is summarised in Table $1 .^{5}$ (The figure given under 'Mime' in Table 1 adds both the directives from Herodas and those from imperial-era mime.)

All texts were read at least once, and the data collected by hand. itur in antiquam siluam: that is let us begin our journey into this silua, or $\tilde{\nu} \lambda \eta$, the stuff or material of our directive database.

5 Wilson (2007) for Aristophanes, Arnott (1979-2000) for Menander, Cunningham (2004) for Mime, and Burnet (1905) for Plato. 
Appendix 1 lists the types of directive that occur in this corpus. A glance at this Appendix hints at the rich variation in the ancient Greek directive system. ${ }^{6}$ As mentioned, we investigate in this essay that most prototypical of the Greek directive, the imperative. There are several reasons for doing so.

First, of all directives, the imperative is the most frequently attested. It constitutes $64.0 \%$ of the directives in Aristophanes, $70.3 \%$ in Menander, $41.7 \%$ in Plato, and $75.2 \%$ in the mime. It's worth noting, incidentally, that those authors who represent every-day conversation-Aristophanes, Menander, and the mime-writers-yield the highest proportion of imperatives. The proportion is remarkably lower in the Platonic dialogue, perhaps because it conveys the cultured conversation of educated Athenians. Second, if we are to generalise based on a sample of data, we should like our sample to be as large as possible - and our sample of Greek imperatives is sufficiently large. Third, in many languages, the imperative attracts mitigators to itself, like our English 'please'; and 'if you wouldn't mind'; the equivalent Greek mitigators being

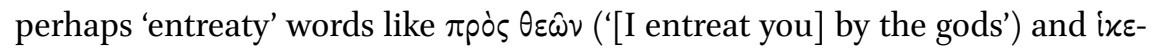
$\tau \varepsilon \dot{\omega} \omega$ ('I beseech you'), in addition to conditional phrases like $\varepsilon \grave{l} \delta 0 x \varepsilon \hat{\imath}$ ('if it's ok with you'), among others. As we will see, these are rare, and their very rareness indicates that, in these words, we do not have softeners per se, but polite 'boosters' - expressions used when the routine way of requesting is not enough (Dickey 2016a: 241).

One may object that my scope-imperatives only—is arbitrary. There are other ways of expressing requests that are not imperatives, which, however, convey similar speech act force(s). For instance, while the present imperative $\left(\pi 0^{\prime} \varepsilon l\right)$ exists in negated form ( $\left.\mu \dot{\eta} \pi 0^{\prime} \varepsilon l\right)$; there exists no similar complement for the aorist imperative, that is, we have $\pi$ oin $\sigma \alpha$ or or $\pi$ oin $\sigma 0 v$ but not * $\mu$ '

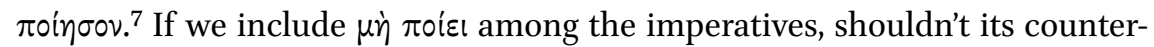

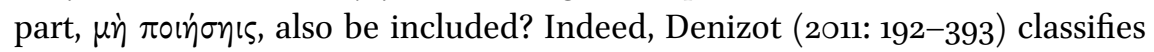
her data in this way: verb morphology that directly conveys commands or requests is identified as 'injunctive'. And while there is an aspectual difference between forms like $\mu \eta \dot{~ \pi o i \varepsilon ı ~ a n d ~ t h o s e ~ l i k e ~} \mu \dot{\eta} \pi \circ i \dot{\sigma} \sigma \varsigma$ - with the former generally expressing inhibitives ('stop doing'), and the latter prohibitives ('don't

6 Denizot (2011) is an excellent overview of the semantic and pragmatic characteristics of many of these forms.

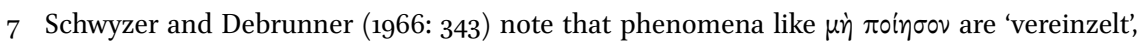
isolated. 
do') — there does not seem to be any difference in politeness. ${ }^{8}$ But I leave out the latter, forms like $\mu \eta \dot{\eta} \pi \circ i^{\prime} \sigma \eta \varsigma$, for this study. For even if we assume that the

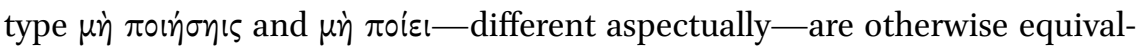
ent, the former type are few in number, constituting between $1.0 \%$ to $4.0 \%$ of the total directives, depending on the author. ${ }^{9}$ Including them would probably not change our results.

The Greek imperative is the chameleon of the directive system, assuming its particular tone from the speech situation and context within which it is embedded. Consider the following examples. ${ }^{10}$

$$
\begin{aligned}
& \text { [2] Herodotus 1.155.3 (Croesus advises Cyrus) }
\end{aligned}
$$

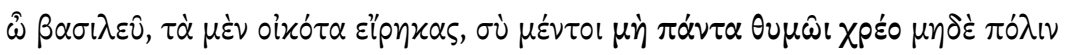

O King, you've spoken what's fitting, but don't vent your anger and destroy an ancient city.

Croesus, given the role of advisor to the Persian king, accordingly advises the king on what not to do, using an imperative form.

[3] Menander Dyscolus 375 (the Slave Daos responds to Sostratos, who has expressed his desire to work in the country)

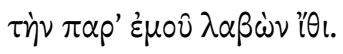

Take this [mattock] from me and go.

Sostratos, the young man in love of the play, wants a mattock in order to depart to Knemon's farm. His slave offers him his own and tells him to go ahead to the farm. (Similarly, a parent would offer an ice cream cone to a child who wants ice-cream, saying 'take it'.) Thus the imperative in passage [2] gives the

8 Schwyzer and Debrunner (1966: 343, section 3) on possible differences; but see now especially Denizot (2011: 287-290).

9 Herodas and imperial mime, 11 of the total 278 directives (4.0\%); Menander, 18 of the total 830 (2.2\%); in Plato these are less than $1 \%$ of the total directives ( 1 of the 139 total); in Aristophanes, the type constitutes 61 of the total 3223 directives, or $1.9 \%$.

10 I use the same examples presented by Dickey (2016a: 239-240), who, however, employs them to a different purpose. 
'green light' to an addressee, allowing the hearer to do whatever desire he or she had previously made manifest. Thus, the imperative constitutes a permission.

In this passage, Pan, rustic god, with a shrine in the deme of Phyle, addresses the audience viewing Menander's Dyscolus.

[4] Menander Dyscolus 1-3, 45-46

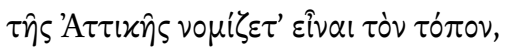

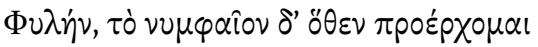

$\Phi v \lambda \alpha \sigma^{\prime} \omega \nu$

$[\ldots]$

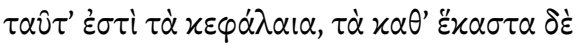

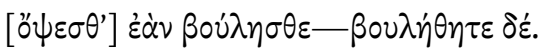

Take this place to be in Attica, Phyle, to be precise; and the Nymphaeum whence I came as belonging to the Phylasians

$[\ldots]$

These are the chief points; but as for the particulars, you will see them if you want. Do want!

Here Pan tells the audience how he wants them to view the stage; he then commands them, with an aorist imperative, to 'want' to view the drama.

In assigning the illocutionary point (whether advice, permission or command) conveyed by the imperative, I have used my own judgment. Different researchers may see the same imperative differently: alii aliis modis. Thus, a reader might plausibly understand [2] as a command.

But all scholars agree that the imperative can convey one of a variety of directive speech acts: advice, permission, commands, and more. Denizot notes that we find imperatives addressed to a god just as we find the imperative used in insulting language, and she concludes that 'the palette of the effects of the sense linked to the imperative is [...] great' (2011: 488). Considered in isolation, wrested from any context, the imperative appears to be neutral with respect to politeness. It must be so, for speakers to employ it in a wide variety of speech situations, and to convey all kinds of illocutions (commands, requests, permissions, advice). ${ }^{11}$

11 To this extent, then, I do agree with Denizot (2011: 488) when she says 'that we must certainly admit that this form [...] is itself neutral from the point of view of politeness.' 
But the imperative always appears in a context, and in some contexts, the imperative alone won't do. Some added politeness is called for, specifically when the imperative represents an imposition on the hearer, when that hearer is of equal or greater status than the speaker (as in passage [2], above) or when the addressee is not known to the speaker (passages [7] and [9], below).

Yet for Greek authors, the imperative was the paradigmatic form for com-

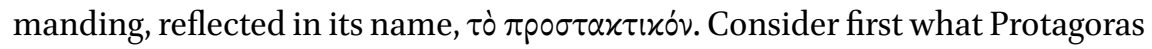
says about the imperative. Aristotle quotes Protagoras' statement in the Poet$i c s$. The philosopher of Stagira has been discussing style, and says that the parts of speech - what we would call the various illocutionary forces an utterance could take-fall under the head of style, or $\lambda \dot{\varepsilon} \xi \iota \varsigma$, that is,

\section{[5] Aristotle Poetics 1456b11-19}

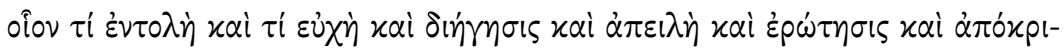

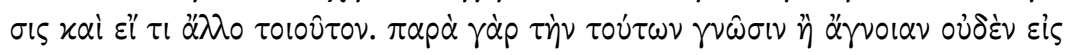

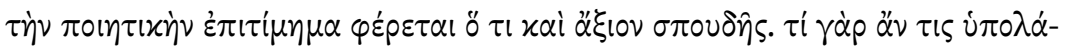

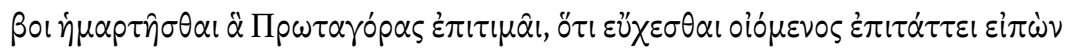

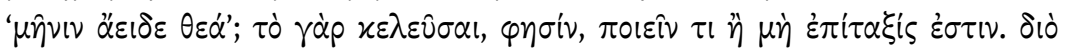

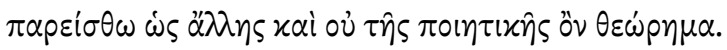

what sort of thing a command is, a prayer, a statement, a threat, a question, an answer, and so on. For as to knowledge or ignorance of these things, no censure worth the effort is imputed to Poetry. What would anyone suppose to have been done wrong in what Protagoras criticises? Since Homer, intending to pray, instead commands, when he says, 'Of the Rage, Sing, Goddess.' 'For ordering someone to do something or not,' he says, 'is a command.' Being an investigation more appropriate to another field than that of poetry, let this be left to the side.

Aristotle chooses to forgo discussing the precise speech-act value of the imperative, $\ddot{\varepsilon} \iota \delta \varepsilon$, but we should not. Invocations at the beginning of hexameter poetry often contain the imperative (Homer Od. 1.1; Hes. Op. 1-2). Incidentally, particularly aorist imperatives are typical in prayers to a divinity. ${ }^{12}$ Finally, the vocative, $\theta \varepsilon \dot{\alpha}$ or the like, must be considered in conjunction with the imperative, since it frames the entire interaction as one taking place between a human worshiper and a god. In such a speech situation, there is no question of commanding. 
Some five centuries later, Apollonius Dyscolus, the late second century CE grammarian from Alexandria, concurs with Protagoras, in his work On Syntax (Apollonius had been talking about whether there exists a first-person command, and presents an argument against):

\section{[6] Apollonius Dyscolus De constructione 3.105.2-5 Lallot}

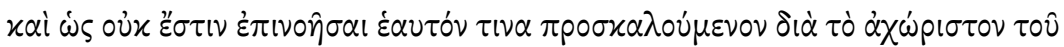

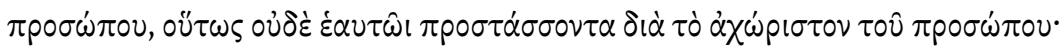

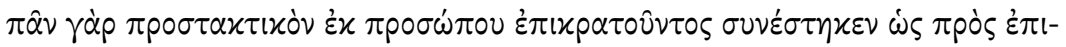

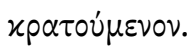

And as it is not possible to imagine a person addressing himself on account of the indivisibility of the person, so it is not possible to imagine a person commanding $(\pi \rho \circ \sigma \tau \dot{\alpha} \sigma \sigma o v \tau \alpha)$ himself for the same reason. For

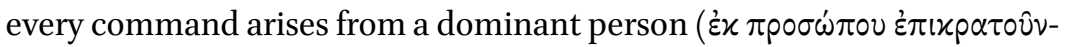

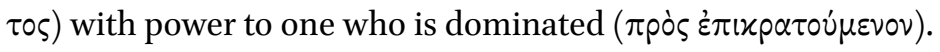

Apollonius had been discussing the distinction between first- and secondperson imperative; and he had had just given as examples of the latter the forms $\varphi \varepsilon \hat{\gamma \varepsilon}, \lambda \varepsilon \dot{\gamma} \varepsilon$, and $\gamma \rho \alpha \dot{\varphi} \varphi \varepsilon$ (3.104.9). But Apollonius considers only one speech

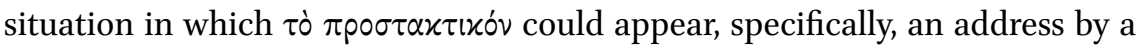
superior to an inferior. In such situations, when superiors command inferiors, we might indeed expect imperatives with little to no mitigation.

In other words, the bare imperative is expected in such situations; while more elaboration is necessary when a power difference exists between the interlocutors, as a first century BCE writer on style indicates (Demetr. Eloc. 7 Radermacher): 'orders are concise and brief and every master is curt towards his slave. Supplication and lamentation, on the other hand, are lengthy' ( $\propto$ ai

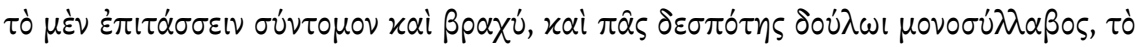
$\delta \varepsilon \dot{~ i x \varepsilon \tau \varepsilon v ं \varepsilon I \nu ~ \mu \alpha x p o ̀ v ~ x a i ~ \tau o ̀ ~ o ́ \delta u ́ p \varepsilon \sigma \theta \alpha i) . ~ A c c o r d i n g l y, ~ t h e ~ b a r e ~ m i n i m u m-e v e n ~}$ a verbless imperative like $\delta \varepsilon \hat{p o}$ ('[come] hither!')—suits addresses by superiors to inferiors; conversely, more elaboration-using vocatives and 'polite boosters'-are necessary when inferiors address superiors or when the imposition is great. 


\section{Characterising the Data in Broad Strokes}

\subsection{Proportion of Imperatives in the Greek Directive Database}

Of course, this is not the first synoptic treatment of the Greek imperative. Here I want to focus on two important, and recent, claims. First, Dickey shows us that the Greeks of the Classical Period very rarely used softeners. ${ }^{13}$ To put this in perspective, compare the proportion of softened imperatives in two very similar authors, the Latin comic poet Terence and the Greek comic poet Menander, both of whom give the impression, if not an actual reflection, of 'real' speech. As I have shown elsewhere, $11.2 \%$ of all imperatives in Menander are softened; while $15.4 \%$ in Terence are. The difference between the proportions is statistically significant. ${ }^{14}$ Terence mimics Menander-he is called by Julius Caesar a dimidiatus Menander (Suet. de poetis 11.103 Reifferscheid) - but not with respect to the softened imperative. The Latin poet probably does not imitate Menander with regard to conversational patterns, preferring instead to model these on what his Roman audience will have heard in their own spoken interactions. This result is tentative-after all, we do not have much Menander or Terence-but it does underscore Dickey's claim, that the Greeks did not incline to softening imperatives.

The second important claim in recent literature is that the bare Greek imperative was used in preference to almost any other form of directive, $65 \%$ of all directives in an ample corpus spanning from Homer to Plato. ${ }^{15}$ Overall, as Denizot says, 'imperatives represent between $75 \%$ and $90 \%$ of the occurrences of verbal types typical of orders' (Denizot 2011: 192) ${ }^{16}$ Based on the numerical

13 Dickey (2016a: 239-240). Perhaps, however, we need to broaden our definition of what counts as a directive softener. For instance, it is possible that vocatives and particles like $\delta \eta$ do play a role in mitigating the directive; on the former, see Barrios-Lech (forthcoming); on the latter, see Denizot (forthcoming).

14 Barrios-Lech (forthcoming); I use the $z$-test to calculate the probability of significant difference. Using the z-test, we can decide whether proportions calculated from two different populations are more likely to originate from two different populations or represent the same population; in other words, whether the difference between the two proportions, calculated from two independent samples, is statistically significant. For further information on this statistical test, see Butler (1985: 92-95).

15 Dickey (2016a: 239), specifically Table A, where the bare imperative represents $65 \%$ of the total directives in her corpus.

16 '[L]es impératifs représentent entre $75 \%$ et $90 \%$ des occurrences de formes verbales typiques de l' injonction.' Her corpus contains Archaic and Classical Greek: Iliad, Odyssey, the extant tragedies of Aeschylus; Herodotus, Aristophanes, Lysias and the early dialogues of Plato (Denizot 2011: 191-192). According to her, Hesiod is the only outlier, in whose texts imperative forms make up only $28.2 \%$ of the texts. 
TABLE 2 Imperatives as a percentage of directives in the Greek directive database

Total directives Imperatives as \% of total

\begin{tabular}{lrl} 
Aristophanes & 3223 & $64.0 \%(2063)$ \\
Plato & 139 & $41.7 \%(58)$ \\
Menander & 830 & $70.6 \%(586)$ \\
Mime & 278 & $75.2 \%(209)$ \\
Total & 4470 & $65.2 \%(2916)$ \\
\hline
\end{tabular}

prevalence of the bare imperative in her Classical Greek corpus, Dickey (2016a) has argued that the present imperative was the 'unmarked' way of 'doing' a request in Classical Greek, much as the 'can you' request is an unmarked way of carrying out a request in English.

In our Aristophanes corpus, we find 3223 directives; of these $2063(64.0 \%)$ are imperatives. Now, in a corpus representing a later stage of Greek, our Menander corpus, there are 830 directives (less $5^{2}$ dubious instances). Of these, there are 219 aorist imperatives, and 292 present imperatives, totalling 511. When we add to this total 28 perfect imperatives (forms like " $\sigma \theta_{l}$ 'know ye'), 47 tokens like $\mu \grave{\eta} \varphi \dot{\varepsilon} \rho \varepsilon$, ('don't bring,' that is, $\mu$ ' + present imperative), we arrive at an overall total of 586 imperatives in our Menander corpus, which represents $70.3 \%$ of all directives in Menander. This proportion (70.3\%) comes close to that calculated by Denizot, $75^{-90} \%$ (depending on the author). So, too, does the proportion calculated from our Hellenistic-era mime corpus: of the 278 directives there, 209 , or $75.2 \%$, are imperatives. Finally, $41.7 \%$ of the directives in Plato's Cratylus are imperatives, so 58 imperatives of 139 directives total. Thus, apart from the Aristophanes and Plato sub-corpora, our figures accord with those of Denizot. And in sum, of the total directives in our corpus, $65.2 \%(2916$ out of 4470) constitute imperatives. Table 2 presents the data in summary form.

In other work, I have shown that, as a whole, the proportion claimed by imperatives in the Greek database differs significantly from that in my Roman Comedy database, the latter corpus representing all the directives in extant Roman comedies: Plautus and Terence. From this Roman comedy corpus imperatives claim $58.4 \%$ of the total directives. ${ }^{17}$ Note the difference, between this proportion $(58.4 \%)$ and that for the Greek corpus, $65.2 \%$ : it is statistic-

17 Barrios-Lech (forthcoming). 
ally significant. Also notice we are not comparing only comedy with comedy, that is Plautus and Terence on the one hand (of all directives $58.4 \%$ are imperatives) with Greek comedy and mime on the other (66.o\%). If we did, the difference between the resulting proportions would be even less likely to be owing to chance.

We have corroboration for Dickey's claim: compared to Roman speakers, Greek speakers appear to have been significantly more inclined to employ the imperative whenever they needed to command, request, instruct, permit, advise, and suggest. Of course, the question naturally arises: what accounts for this difference?

The type of social structure which organised relations between members of a community may have much to do with this difference. In a typical Greek polis, élites or members of the 'in-group' lived together as equals, whether these were citizens of fifth-century Athens or the ojoîo of Sparta. The absence of hierarchical relations between individuals means that the imperative, when used, lacks a context that would give it the value of 'order.'18 By contrast, élite Romans were hyper-aware of factors like auctoritas - roughly the social influence of a person - and dignitas - the esteem to which his standing in society, his family, and accomplishments entitled him. Differences in the dignitas and auctoritas between speaker and hearer needed to be taken into account by the speaker. The resulting wariness about the other's status relative to one's own, and the heightened fear of potentially injuring the other with an untoward remark, might result in the relatively lower proportion of imperatives we see in our Roman texts. ${ }^{19}$

\subsection{How Often Did the Ancient Greeks Soften Their Imperatives?}

4.2.1 Positively and Negatively Polite Softeners; or 'Polite Boosters' and 'Polite Down-Toners'

To anticipate a little, the Greeks in our period seemed disinclined to use what we would consider the most obvious candidates for 'please', again, words like $\dot{\alpha} \nu \tau i \beta 0 \lambda \hat{\omega} \sigma \varepsilon, \pi \rho \dot{\varsigma} \varsigma \theta \varepsilon \hat{\omega} \nu$, i $\varkappa \varepsilon \tau \varepsilon \dot{\omega} \omega$. Dickey demonstrates not only that these are rarely used, but that they did not go down the path of grammaticalisation over time (Dickey 2016a: 242-243, 245-246). Nevertheless, let us try to characterise the Greek 'words for please.' On the one hand, 'polite boosters', entreaty-words, simultaneously make the request urgent and ingratiate the speaker with the

18 Dickey (2016a: 249) and (2016b).

19 Barrios-Lech (forthcoming) on the Roman disinclination to the present imperative compared to the Greek; on social factors, see Unceta-Gómez (2009: 43) and Kaster (2005: 28): the relevant social emotion is uerecundia. 
addressee. Vocatives, for instance $\gamma \lambda \nu$ to the hearer's close connection with the speaker, or instantly forge such a close connection (much like the British-English address-term 'love'). In Greek, we also have 'polite down-toners', words that minimise ( $\mu$ óvov, 'just' do this) or Bpaxu ('just a bit'); and phrases that make the imposition optional for the

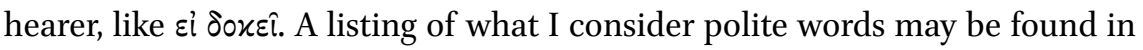
Appendix 2.

Two concepts familiar in politeness theory can help us to organise this data: negative and positive politeness. ${ }^{20}$ Positive politeness emphasises a connection with the addressee ('hey brother, can you spare a dime?'; or 'be a dear and hand me my scarf, will you?'), while negative politeness maintains respectful distance from the addressee ('I was wondering if you wouldn't mind covering my shift this Wednesday' or 'Sir, may I offer you some advice?'). These terms form part of a theory of Politeness meant to describe modern politeness cultures, but they have proven useful in studies of the language of ancient Greek and Latin. ${ }^{21}$

Positively polite, then, is Habrotonon's - the good courtesan in Menander's Epitrepontes-request of a young woman. Habrotonon, aware that her addressee may in fact be the mother of an abandoned child, asks a key question:

[7] Menander Epitrepontes 862-863

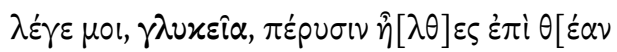

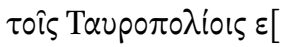

Tell me, honey, did you go last year to the Tauropolia?

The vocative $\gamma \lambda u x \varepsilon i \alpha$, here, expresses the courtesan's affection for the young woman; similar is $\varphi$ i $\lambda \tau \alpha \alpha \tau \varepsilon$ (or $\varphi i \lambda \tau \alpha \dot{\tau} \tau)$ ), 'one of the most common friendship terms and expresses very strong and genuine affection' (Dickey 1996: 358). This, too, can express positive politeness. The nurse in Menander's Dyscolus makes a positively polite request of her addressee, to go down a well to rescue the misanthrope - in addition to a mattock - that have fallen in. Certainly, this is not a routine request, nor is she in the position to be making requests-she is a servant—so she must frame it politely: $\varphi(\lambda \tau \alpha \tau \tau \varepsilon, \kappa \alpha \tau \dot{\beta} \beta \alpha$. (Dys. 632). It bears not-

20 The seminal text is that of Brown and Levinson (1978), reprinted with new introduction in 1987 .

21 A full bibliography is not possible here: for a good starting point in Greek, see Denizot (2011); for Latin, see now Unceta-Gómez (2018). 
ing that her addressee, the cook Sikon, is also of low-status. In fact, the cook had made a similar request of the old woman, to 'finish the work' by throwing rocks on top of the unlikeable old man in order to murder him. The cook softens the urgent—and joking—appeal with the similar $\hat{\omega} \varphi 1 \lambda \tau \dot{\alpha} \tau \eta \eta \gamma \rho \alpha \hat{v}$ ('It's your job now, love, to take a mortar or a stone and thrown it down on him': $\hat{\omega} \varphi i \lambda \tau \dot{\alpha} \tau \eta \eta \gamma p \alpha \hat{v}$,

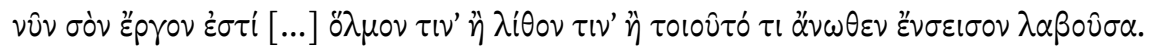
Men. Dys. 630-632).

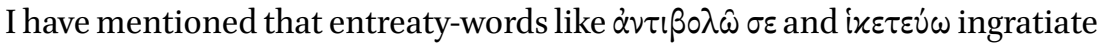
the speaker with the hearer. They would appear to be tokens of positive politeness, but prove, in practice, more difficult to classify. Consider the following passage, in which Dicaeopolis asks Euripides for some rags so he can dress up like Telephus and take a charcoal basket hostage (just as Telephus had taken the baby Orestes hostage in the lost Euripides play).

\section{[8] Aristophanes Acharnians 431}

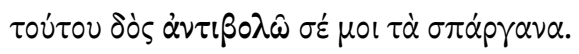

Give me, I beg you, the rags of this man.

$\dot{\alpha} \nu \tau i \beta \lambda \hat{\omega}$ may count as an instance of positive politeness, since with it the speaker pays the addressee the compliment of elevating his or her status, while humbling himself. But this move, self-humbling, distances self from other. So $\dot{\alpha} \nu \tau i \beta \circ \lambda \hat{\omega}$ and the like may function as a negative politeness particle-this is how Sorrentino (2013: 191-192) sees it, for example. In either case, such entreaties leave the addressee very little option to refuse fulfilling the request. When we consider what other words appear alongside the recurrent $\alpha \nu \tau i \beta 0 \lambda \hat{\omega} \sigma \varepsilon$ and

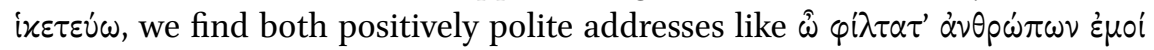
(Ar. Nub. 110), but also the negatively polite $\hat{\omega} \delta \dot{\varepsilon} \sigma \pi 0 \tau \alpha$ (Ar. Eq. 960). Most frequent alongside $\dot{\alpha} \tau \tau i \beta 0 \lambda \hat{\omega}$ are strengtheners like $\dot{\theta} \theta$ and $\alpha^{\prime} \gamma \varepsilon$. Similarly, when $i x \varepsilon-$ $\tau \varepsilon \dot{v} \omega$ appears with other modifiers, we find both positively and negatively polite

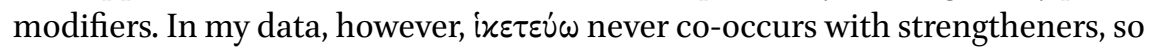
that there is a case to be made either that, of the two, it was the less-urgent form of entreaty. ${ }^{22}$

These 'entreaty' words originate from the language of prayers. In prayers

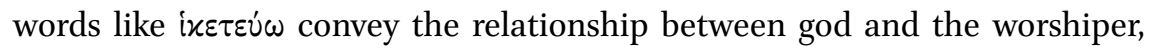

22 Of course, one could make the opposite argument: that it was already urgent enough so that no added strengtheners were felt necessary. 
at once distant and intimate, so that, appearing with 'entreaty' words we find

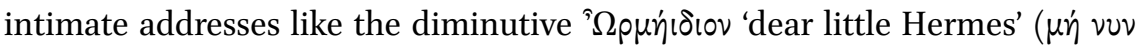

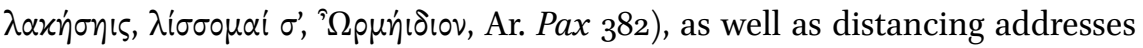
like $\Theta \varepsilon \sigma \mu \circ \varphi o ́ \rho \omega ~ \pi \circ \lambda v \pi \circ \tau v i \alpha$, 'O Almighty Goddesses of the Thesmophoria', ad-

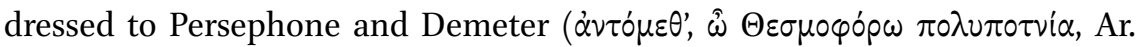
Thesm.1155).

Dickey (2016a: 243) also acknowledges that these entreaty words are difficult to categorise. She prefers to see them as 'markedly' polite, since they deviate from the otherwise unmarked ways of carrying out requests. It makes sense, then, to count them as a different kind of strategy altogether.

Let us consider the following passage which illustrates another kind of negative politeness, that is, 'minimising' requests with phrases like, $\beta p \alpha \chi[\dot{v} \tau$ ':

[9] Menander Dyscolus 299-300 (Sostratos, the city youth, replies to the rustic youth, Gorgias)

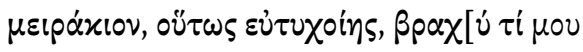

äxovoov.

Young man, may you be fortunate, listen for just a little while.

We first consider the context. Gorgias had accused the rich young man Sostratos of abusing his privilege by taking advantage of a poor young woman (in fact, Gorgias' sister). Sostratos, innocent of the charge, will clear himself, but first he needs to secure Gorgias' attention and good will. It is a crucial moment. ${ }^{23}$

Dickey (1996: 74) notes that in Menander, the address-term $\mu \varepsilon ı \alpha$ xi ı૦ 'appears to be a neutral one, and the usage from one youth to another, as in Lucian, is more polite than otherwise.' The vocative is typical in addresses from one youth to another, so that we may take $\mu \varepsilon ı \rho^{\alpha} \varkappa x_{10 \nu}$ 'young man' as unmarked; that is, it is expected in this kind of interaction. ${ }^{24} \beta p \alpha \chi[\dot{v} \tau i$ ('some little bit'), however, is clearly needed as some form of 'extra' politeness: the unmarked request form will not do, after all. Gorgias is not known to Sostratos, nor can Sostratos be sure that Gorgias wants to listen. So the rich youth promises that the imposition will be a small one, thus indicating respect for Gorgias,

23 Sorrentino (2013: 259-26o, 272) notes the difference in their approaches, with Sostratos inclining to positive politeness; Gorgias by contrast prefers off-record strategies and negative politeness.

24 The address-term varies according to context: for analysis of usage in Menander, see Sorrentino (2013: 257 n. 46$)$. 
as someone who does not deserve or want to be imposed upon at all. He furthermore adds a positively-polite device, wishing Gorgias' success in the future

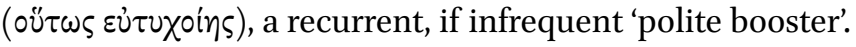

The particular polite value of vocatives-a favoured means of softening directives-depends on the context. When the chorus in Acharnians tell the Theban guest to take a sycophant with him, they make the request polite by adding the address term $\hat{\omega} \xi \dot{\varepsilon} v \omega \nu \beta \varepsilon \dot{\lambda} \tau \tau \iota \tau \varepsilon:$ "reap" him too, in your harvest, and add him to your cargo, bringing him wherever you want, an informer for

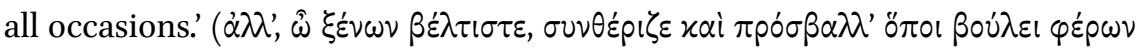

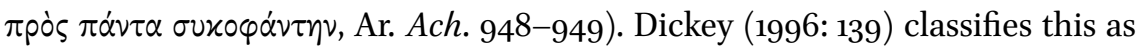
a friendship term, but notes its usages vary depending on the author. Outside of Plato 'authors do not make a [...] distinction between $\beta \dot{\varepsilon} \lambda \tau$ $\sigma \tau \varepsilon$ and other friendship terms.' She adds (1996: 139), however, that in Menander, the term is 'polite and respectful' but it can be used in moments where the speaker claims superiority over the addressee. I have, in general, classified all friendship terms as positively polite. I acknowledge here that, since other readers may classify a given vocative differently, the classification that I rely on for this essay must remain provisional.

\subsubsection{Analysing the Data-Polite Boosters and Down-Toners in the Greek Directive Database}

Scrutiny of the 2063 imperatives in Aristophanes reveals 239 softeners; this means that in Aristophanes, imperatives are softened $11.6 \%$ of the time. In Menander, $11.2 \%$ of all the imperatives are softened (66 out of 586 ), and in Plato's Cratylus, $11.8 \%$ of the imperatives are modified ( 6 out of 51 ). The relevant statistical test shows no significant difference amongst these proportions. ${ }^{25}$ In other words, we see a surprising continuity across genres and time-periods in this respect-at least for the Athens-centred authors.

In Herodas' Mimes, however, 8.5\% of the imperatives are softened (11 out of 129), and the proportion does differ significantly from that given for our Athenian corpus. Herodas, a coeval of Callimachus, probably had connections with the court of Ptolemy II (Cunningham 1971: 2-3), and his mimes convey scenes from the everyday life of individuals inhabiting the lower strata of society. Consider some representative situations: in the first mime, a maid advises a courtesan; in the second, a pimp delivers a courtroom speech; in the fifth, a woman accuses a slave she has been sleeping with of infidelity; in the sixth and seventh, women discuss and shop for $\beta \alpha \nu \beta \hat{\omega} v \varepsilon s$. As for the mimes from 
the Roman imperial period (collected and edited in Cunningham 2004), these show $9.0 \%$, or 7 softeners out of 78 imperatives, similar to the figure that we find in Herodas. The figures for Herodas and imperial mime do not differ significantly, but we have very little data, making statistical tests unreliable.

The Athenian corpus - consisting of different authors writing in different genres and at different times - shows a surprising stability in the percentage of imperatives softened. That continuity is put into striking relief when we compare texts written outside of Athens - the mimes of Herodas-or those texts written during the Roman imperial era.

If we compare data from Roman texts, we can better appreciate the stability of the politeness system across the various Attic texts. In the plays of Plautus and Terence, $9.8 \%$ and $15.4 \%$ respectively of the total imperatives in each author are softened. If we compare, again, two authors quite similar in their approach to the genre, Menander $(11.2 \%$ of all the imperatives are softened) and Terence ( $15.4 \%$ softened), the difference is significant. Further let us compare two similar texts, the Cratylus of Plato and the de Oratore of Cicero, a dialogue on the place of oratory within the traditional 'academic' disciplines. In Plato's dialogue, we found that $11.8 \%$ of imperatives are softened $(6$ out of 51 ); while in Cicero's $17 \%$ of the present imperatives are softened ( 7 of 41).

\subsection{What Kind of Politeness Did the Greeks Incline To?}

We saw that about $11-12 \%$ of the imperatives are softened in our Attic Greek corpus. When we compared Menander with Terence and Platonic with Ciceronian dialogue, we appreciated the Greek disinclination to soften imperatives compared to Latin authors. This difference may point to an underlying reality in language use.

The distinction noted between negative and positive politeness can help us to characterise our data in another, general, way. And one may ask, of the two, which kind did the Greeks incline to? Before beginning, I must admit to misgivings. We have already seen that entreaties perform both positive and negatively polite functions, so that I have found it impossible to categorise the entreaty as one or the other.

As we saw above, entreaty performs both negatively and positively polite functions at once, so that I thought it best to consider it a separate category. In general, we see a preference for positively polite softeners in Aristophanes (see Table 3).

When we compare the Menandrian and Aristophanic corpora (see Tables 3 and 4), we find that are no significant differences in the proportions for Aristophanes and those calculated for Menander. That is, as far as softened imper- 
TABLE 3 Percentage of softeners that are negative, positively polite in Aristophanes

\begin{tabular}{lllll}
\hline & Softeners & NP & PP & Entreaty \\
\hline Total softeners & 239 & 71 & 126 & 42 \\
Percent of total & $100 \%$ & $29.7 \%$ & $52.7 \%$ & $17.6 \%$ \\
\hline
\end{tabular}

TABLE 4 Percentage of softeners that are negative, positively polite in Menander

\begin{tabular}{lllll}
\hline & Softeners & NP & PP & Entreaty \\
\hline Total softeners & 66 & 23 & 26 & 17 \\
Percent of total & $100 \%$ & $34.8 \%$ & $39.4 \%$ & $25.8 \%$ \\
\hline
\end{tabular}

atives go, the sets of data-negative, positive, and entreaty-type imperative softeners - come from the same population, and that population can be characterised as either (1.) the language of Athenian comedy; or (2.) the colloquial idiom of Athens.

Let us turn to the Platonic subcorpus. Here, we find 10 imperative softeners. Of these imperative softeners in Cratylus, 6 are negatively polite (6o\%) and 4 are positively polite ( $40 \%)$; one entreaty-form is used, representing $10 \%$ of the total softeners. The relevant statistical test indicates no significant difference between our Platonic subcorpus and either the Aristophanic or Menandrian. But we would need more data to be certain of this result; for with the data we have the test is not reliable.

Let us tentatively conclude from this agreement across our three Attic genres-Old Comedy, New Comedy, and Platonic dialogue — that the language of Greek politeness across the period we are considering shows a stability that is perhaps surprising. While we can interpret the continuities we have observed, with Dickey, as owing to the conservativism of authors using an established literary idiom, I personally am inclined to think that those regularities across different authors point to actual and pervasive habits of speech. To characterise the politeness culture, however, will take a more ample study than can be attempted here: we need to take into account more relevant data from Plato's and Xenophon's dialogues and to consider other kinds of im/politeness phenomena. 
TABLE 5 Percentage of softeners that are negative, positively polite in Herodas

\begin{tabular}{lllll}
\hline & Softeners & NP & PP & Entreaty \\
\hline Total softeners & 11 & 3 & 7 & 1 \\
Percent of total & $100 \%$ & $27.3 \%$ & $63.6 \%$ & $9.1 \%$ \\
\hline
\end{tabular}

Let us now consider the Mime subcorpora, both the mimes written by Herodas and those dating from the Roman imperial era. These give us an indication - although no firm proof - that the polite language — specifically the softeners - of the Attic authors stands apart.

Under a third of the softeners are negatively polite; nearly two-thirds are positively polite. There are very few data, and even fewer from the imperialera mime, where all of the strategies consist of respectful vocatives like xupia and $\delta \dot{\varepsilon} \sigma \pi \circ v \alpha$. For our data (culled from imperial-era mime), the use of these vocatives appears to be a negatively polite strategy (although I grant that such characterisations retain an element of subjectivity).

In particular, and again, for the imperial period, the addresses xúpı and xupi $\alpha$ derived from a Greek translation for the Latin domine. Their use increased in the second century $\mathrm{CE}$; the forms could be directed equally to superiors as to friends, relatives, and equals. In the same century, $\delta \dot{\varepsilon} \sigma \pi 0 \tau \alpha$ and $\delta \dot{\varepsilon} \sigma \pi \circ v \alpha \alpha$ were most often used toward superiors. ${ }^{26}$ The evidence from our Roman imperial mime database shows the forms being directed in all cases to superiors. ${ }^{27}$ Indeed, there are too few data to perform a reliable statistical test. Future work will need to look at texts imitating spontaneous speech from the later periods. Probably most illuminating will be to consider the wealth of data available from the second sophistic, and particularly the dialogues of Lucian; and compare these with the conclusions given here, for Athens.

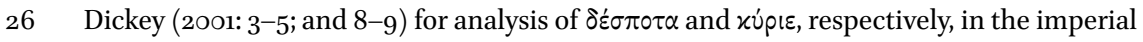
period. All examples of the vocative xupi $\alpha$ in my mime database come from the papyrus P.Oxy. 413 (accessible both in the Cunningham volume and also in the Loeb edition, Page [1941: no. 76]), dated to the Roman Imperial period, second century CE.

27 In P.Oxy. 413, at lines 27, 42, 107, 123, 135, a (presumably) lower-status character addresses a superior (I say 'presumably' because the state of the papyrus permits only guesses at speaker-identity for some verses). In the same papyrus at line 106, Charition prays to a goddess, addressing her with $\delta \dot{\varepsilon} \sigma \pi \circ \vee v \alpha$. 
TABLE 6 The top 4 styles of politeness used in Aristophanes

Type of softener Totals

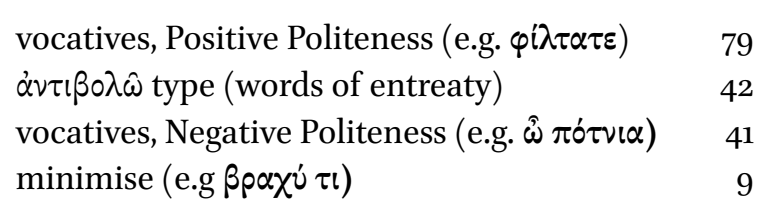

TABLE 7 The top 4 politeness styles used in Menander

\section{Type of softener Totals}

\begin{tabular}{|c|c|}
\hline vocatives, PP & 18 \\
\hline$\alpha \nu \tau ı \beta о \lambda \hat{\omega}$ type & 17 \\
\hline minimise & 11 \\
\hline vocatives, NP & 6 \\
\hline
\end{tabular}

\subsection{What Kinds of Polite Expression Are Used?}

Tables 6 and 7 show the four most recurrent Politeness strategies in our comedies. Other kinds of Politeness are used, of course, but these are by far the most prevalent. Appendix 2 lists other kinds of politeness that we find in the Aristophanes corpus, in addition to the types mentioned above. What do we find in Menander, writing about a century later, in a different genre, and under a different regime?

Again, we find continuities. Even though entreaty words like $\alpha \dot{\nu} \tau \beta \circ \lambda \hat{\omega}$ and

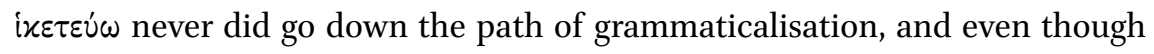
the Greeks, compared to the Romans, were disinclined to soften their imperatives, when they did, words of entreaty were often used, as were vocatives. Here, again, there is a stark difference from the material we find in the Latin data, where vocatives were significantly less often used. ${ }^{28}$

28 Barrios-Lech (forthcoming); on entreaty-words in the Greek data, see Dickey (2016a: 246). 
TABLE 8 Politeness styles used in Herodas' Mimes

Type of softener Totals

\begin{tabular}{|c|c|}
\hline vocatives PP & \\
\hline Hedges (e.g. દi $\varphi ા \lambda \varepsilon \hat{\zeta} \varsigma \mu \varepsilon$ & \\
\hline Wishes & \\
\hline$\dot{\alpha} \nu \tau i \beta 0 \lambda \hat{\omega}$ type & \\
\hline Vocatives NP & \\
\hline$\varphi 1 \lambda \hat{\omega} \sigma \varepsilon$ & \\
\hline
\end{tabular}

\section{Conclusion}

The data from Herodas can be considered, even though there are too few items for reliable conclusions to be drawn.

Here, vocatives again stand out as a recurrent means for softening imperatives. The expression of a wish in the addressee's benefit, that is, variations on 'may you be blessed' ov́] $\tau \omega \varsigma$ ơvalo (Men. $P k .400$ ), recurs as a politeness phrase throughout our corpus, and appears twice in Herodas. It may have been a colloquial feature. ${ }^{29}$ Herodas diverges from what we have seen in the types of expression used, particularly the use of hedges like $\varepsilon i \varphi(\lambda \varepsilon \hat{\varsigma} \varsigma \mu \varepsilon$ and formulas like oư $\tau \omega \varsigma$ o ovalo. The latter do appear in Aristophanes and Menander but claim only a small percentage of the total softeners (though it should be noted that expressions like oü $\tau \omega \varsigma$ ővaı are used fifth-most-often in Menander).

The figures from the mimes presented in Cunningham's Teubner volume also diverge from the corpus of Greek comedy: there, all seven imperative softeners are negatively polite. Six of the total seven are vocatives, which, as we have seen, is a characteristically Greek way to soften imperatives. We also find one minimiser ( $\mu$ óvov, 'just' do). These latter texts date mainly to Rome's imperial period.

Thus, it looks like the Attic subcorpus, consisting of all the plays of Menander and Aristophanes, as well as Plato show stability in the percentage of imperatives softened and the kinds of politeness used. The mime corpus stands apart, but that divergence may be only an illusion, since our mime subcorpus yields

29 Ferri (2015: 503-504) collects some examples of this and related expressions. It was probably a polite formula, with elegant variations possible. 
few data to work with. To appreciate the uniqueness of the politeness system in the Attic subcorpus, we will need more ample data from a different place or time; a suitable candidate will be the Greek of the second sophistic, when the Hellenistic world will have felt the impact of Romanisation. ${ }^{30}$

\section{Appendix 1: Types of Directives, Aristophanes (Items in Bold Are Polite $)^{31}$}

- 1st plural hortatory subjunctive (ex. Ach. 627 the chorus has been convinced by Dicaeopolis. They exhort each other to take off their garments and begin

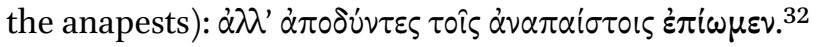

\section{- Questions}

- 2nd person future indicative in a question (ex. Ach. 55, the divine Amphitheos, under arrest by Skythian archers, calls upon the gods for help): $\hat{\omega}$

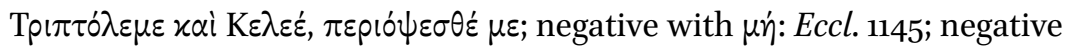
with ov่ $\mu \eta \dot{~(e x . ~ N u b . ~}{ }_{367}$, Strepsiades asks whether Zeus isn't a god, and

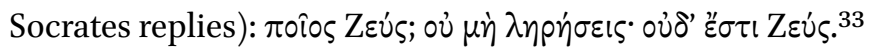

- 1st person plural future indicative in a question (ex. Lys. 356).

- oủ +2 2nd person future indicative in a question (ex. Ach. 822, see below for

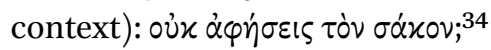

- 2nd person present or perfect indicative in a question (ex. Ach. 483-484, Dicaeopolis encourages his spirit to go forward and debate with the

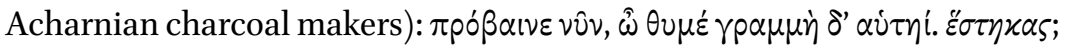

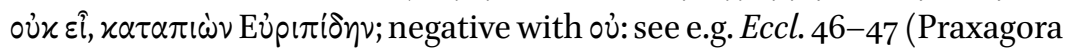

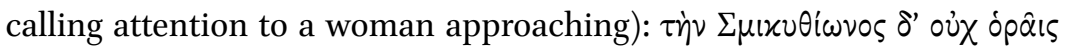

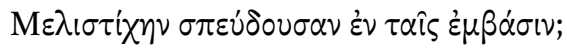

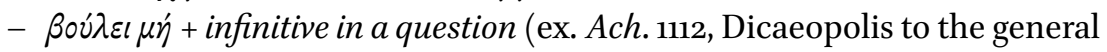

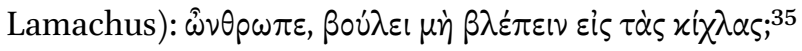

$30 \quad$ For one step in this direction, see Dickey (2009).

31 The items marked as polite are requests documented as polite in the secondary literature; if the item is not in bold, it is either not polite; its politeness is context-dependent; or I have not been able yet to ascertain its politeness. I refer throughout in the notes for further reading to Denizot (2011), an up to date and comprehensive account of the Greek directive.

32 Polite: Denizot (2011: 268).

33 On the difficulty of identifying the former as true questions, see Denizot (2011: 457): on the latter, with ov $\mu$ '́, see Denizot (2011: 476-483): not polite.

34 Impolite: Denizot (2011: 469-473).

35 Polite; but can be used to convey ironic politeness: Denizot (2011: $45^{8-459)}$. 
- $\tau i(o \mho)+$ present or perfect (ex. Ach. 410, Euripides tells Dicaeopolis to keep

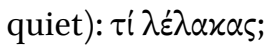

- Tag questions (ex. Ran. $5^{22}$ and 526, Xanthias in the latter asks Dionysus

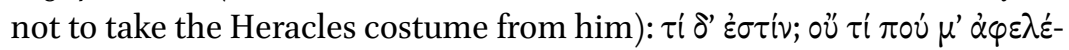

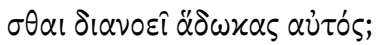

- 'Whynot'-questions (ex. Ran. 635-636, where Dionysus suggests that since

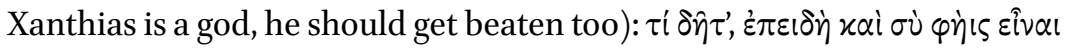

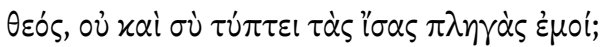

\section{- Statements}

- 2nd person future indicative in a statement with $x \lambda \alpha \dot{\alpha} \omega$ : (ex. Ach. 822, the informer tries to seize contraband from a Megarian): $x \lambda \dot{\alpha} \omega \nu \mu \varepsilon \gamma \alpha p เ \varepsilon \hat{\varsigma}$, 'you'll be sorry if you side with the Megarians.' ${ }^{36}$

- 1st person future indicative in a statement (ex. Lys. 1230).

- ov $\mu \dot{y}^{\prime}+2$ 2nd person present indicative in a statement (ex. Ach. 165-166, the ambassador tells Dicaeopolis not to approach the Thracian mercenaries,

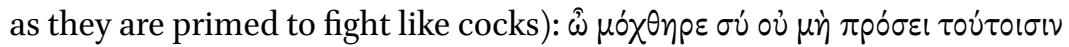

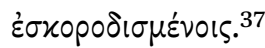

- 1st person plural aorist indicative (ex. Lys. 181-182, the title character

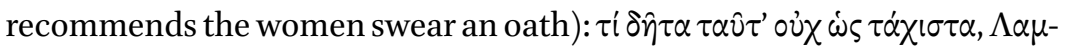

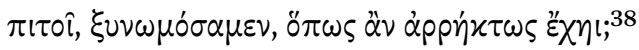

- Imperatives

- Aorist Imperative

- Perfect Imperative

- Present Imperative

- Infinitives

- Aorist Infinitive (ex. Ach. 130-131, Dicaeopolis asks Amphitheos to go

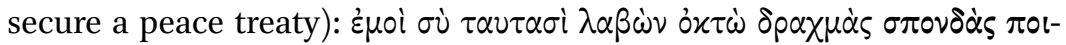

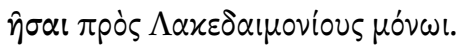

- Present Infinitive (ex. Ach. 172, the herald tells the Thracians to come the

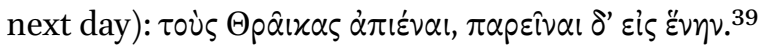

36 Speech act value and politeness of the and person future indicative in statements are highly context-dependent; when used alone like this they tend to be impolite: see Denizot (2011: 431-433).

37 A strong prohibition: see further Olson (2002: ad loc.).

38 Here we might be tempted to see an example of what Lloyd (1999: 33-35, esp. 33) calls ' $[t]$ he distancing effect of the tragic aorist' which 'is often used to make a verb more polite than it would have been in the present'. But these types of question with $\tau i$ and the aorist do also convey urgent commands: see Denizot (2011: 46o).

39 On the infinitive, a neutral form, most like the imperative in its morphology, see Denizot (2011: 336-339). 
- Speech Act Verb (ex. Ach. 169, Dicaeopolis does not want to have an assembly called about the matter of wages for the Thracian mercenaries): $\dot{\alpha} \lambda \lambda^{\prime} \dot{\alpha} \pi \alpha \gamma 0-$

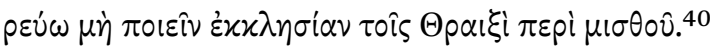

- Impersonals ${ }^{41}$

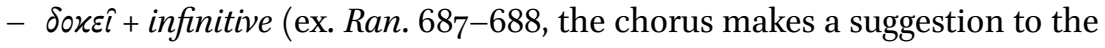

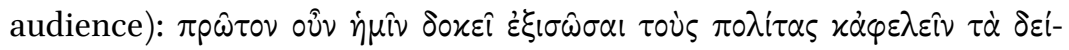
$\mu \alpha \tau \alpha$

$-\chi \rho \dot{n}+$ infinitive

- $\delta \varepsilon \hat{\imath}+$ infinitive (ex. Ach. 233, the chorus looks for the person who has con-

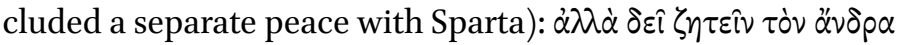

- है $\sigma \tau l+$ infinitive (ex. Pl. 576-577, Dicaeopolis allows Peloponnesians to

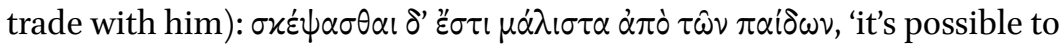
see this especially using the example of children' (= 'consider the example of children'). ${ }^{42}$

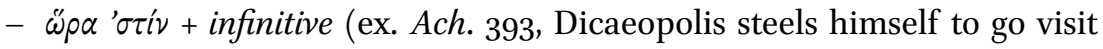

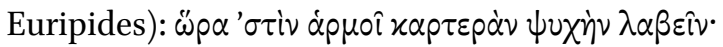

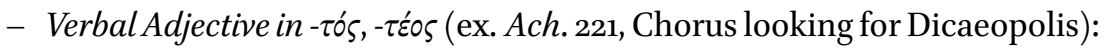

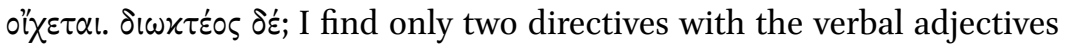

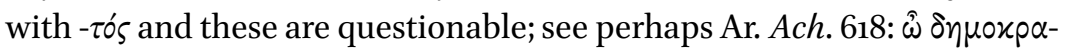

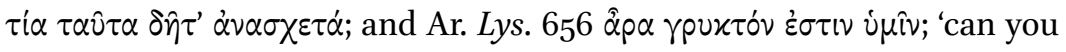
possibly grumble?'

- Eixós + copula + infinitive (ex. Eccl. 493-494, the chorus of women does

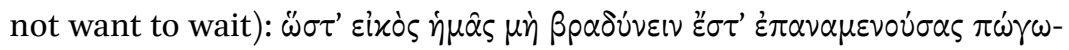
vas $\dot{\varepsilon} \xi \eta \rho \tau \eta \mu \dot{\varepsilon} v \alpha \varsigma$

- бov हैpyov + infinitive (ex. Eccl. 514, where the chorus asks Praxagora to tell

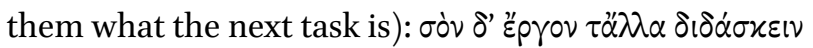

\section{- Conditional Clause}

- $\varepsilon i+2 n d$ person present indicative, 2nd person future indicative (ex. Nub.

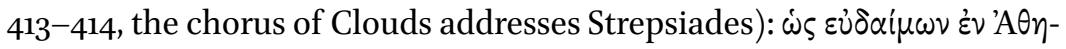

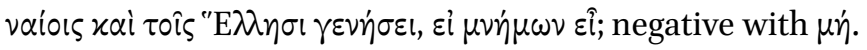

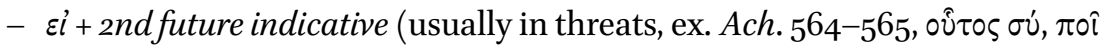

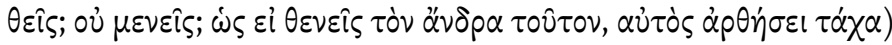

40 The politeness value will, of course, very much depend on the speech-act verb. Here $\dot{\alpha} \pi \alpha-$ ropev́w presents a strong prohibition.

41 On the deontic impersonals, see Denizot (2011: 400-409): since these propose the action as something that 'should or ought' to be done, they can be used to express polite directives.

42 These can have a directive function in the right context; admittedly interpretation is difficult, and opinions will vary on whether a given example counts as a directive. 


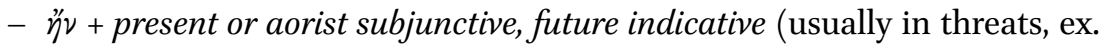

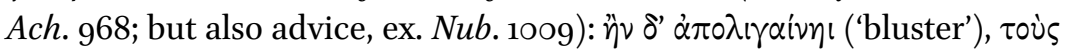
àopavónous $x \alpha \lambda \hat{\omega}$

- $\varepsilon i \mu \eta^{\prime}+$ future indicative, ov( $(x) \ddot{\alpha} v+$ aorist optative (ex. Eccl. 162-163, Praxagora insists the women get things right before they proceed in disguise to

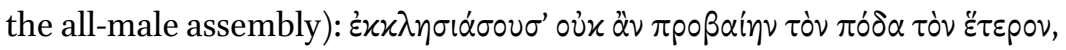

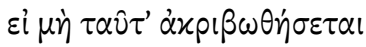

- (öpa) ö $\pi \omega \varsigma+2 n d$ person future indicative (ex. Ach. 253-254, Dicaeopolis asks his daughter to lead a procession in honor of Dionysus): $\alpha^{\prime} \gamma^{\prime}, \hat{\omega} \theta \dot{\gamma} \gamma \alpha \tau \varepsilon p$, ö $\pi \omega \varsigma$

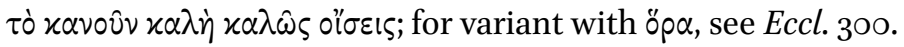

- Prohibitives

- $\mu \eta^{\prime}+2 n d / 3 r d$ person aorist subjunctive (ex. Ach.334, the chorus tries to prevent Dicaeopolis from murdering a charcoal basket, à la Telephus): $\alpha \lambda \lambda \dot{\alpha}$

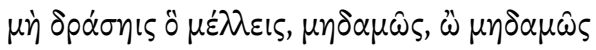

- $\mu \eta^{\prime}+2 n d / 3 r d$ person present imperative (ex. Ach. 334, the chorus does not

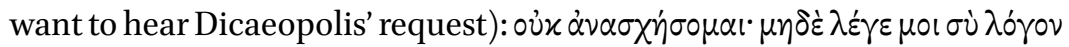

$-\mu \dot{\eta}+2$ 2nd person present subjunctive (ex. Eccl. 437):

- Optative

$-o \dot{v}(\varkappa)+1 s t$ person aorist plural optative + àv (ex. Lys. 309; the chorus of old men exhort each other to kindle the fire and charge the gates):

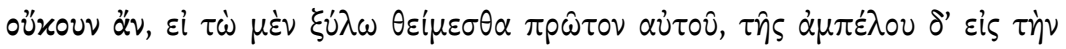

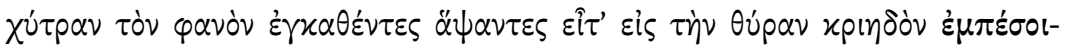
$\mu \varepsilon v$.

- 2nd person present optative $+\ddot{\alpha} \nu$ (ex. Eccl. 132, Praxagora tells someone to speak in the mock-assembly): $\lambda \varepsilon^{2} \gamma o r \varsigma \alpha \alpha \nu$ (but see Ran. 436, Dionysus to his

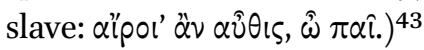

- $\varepsilon^{\prime} \vartheta \varepsilon+2 n d$ person aorist optative in a wish-like construction (ex. Eq. 618-619, where the Knights ask the sausage-seller to relate what happened in the

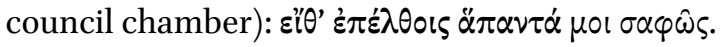

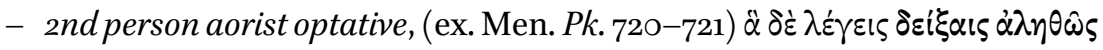

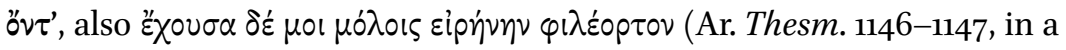
prayer to Athena; cf. Thesm. $368-371$; and $1229-1231) .{ }^{44}$

43 See Schwyzer and Debrunner (1966: 329) on the use of the potential optative as a polite form 'einer Willensäußerung, Bitte, Aufforderung'. But the expression may not be polite per se; context will be important in determining whether it is polite or not. For, as in the the example from Aristophanes' Frogs, cited above, the 2nd person present optative $+\alpha 2 v$ can also be used to express peremptory commands; see also, from a tragedy, Soph. El. 1491

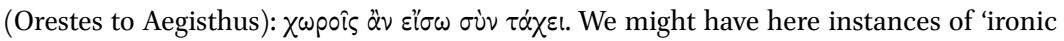
politeness' where politeness is employed to express its opposite.

On this kind of optative, where the speaker dissociates himself from the 'situation d'énon- 


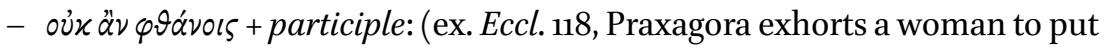

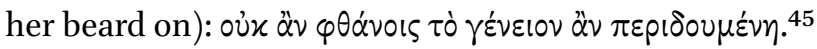

- Verbless Imperatives (ex. Ach. 864, Dicaeopolis speaking to the Theban and

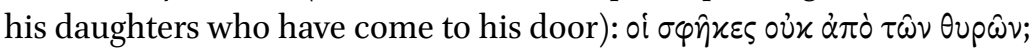

\section{Appendix 2: Types of Politeness Used in Greek Comedy}

\section{Type of softener / Politeness type Example phrase}

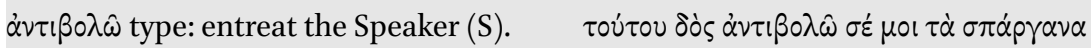
Positive and Negative Politeness. ${ }^{46}$ (Ar. Ach. 431)

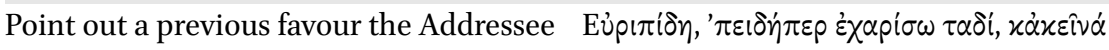
(A) had done. Positive Politeness. ${ }^{47}$

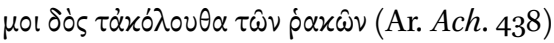

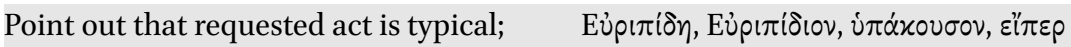
one that A has done before, often. Positive $\tau \dot{\omega}^{\prime} \pi \circ \tau^{\prime} \alpha \dot{\alpha} \theta \rho \dot{\omega} \pi \omega \nu \tau \tau i v i($ Ar. Ach. 405) Politeness. ${ }^{48}$

Minimise. Negative Politeness. ${ }^{49}$ róvov

Don't assume A is willing. Negative Polite- $\alpha i \lambda \hat{\eta 1 s ~(A r . ~ A c h . ~ 772) ~}$ ness. ${ }^{50}$

Don't assume A has time. Negative Politeness. ${ }^{51}$

$\sigma i \dot{~ \delta ’ ~ \eta े \nu ~ \sigma \chi \chi ~}$

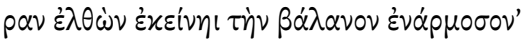
(Ar. Lys. 411-412)

ciation', expressing a desire, and leaving it up to others to carry out the implicit request, see Denizot (2011: 445-455).

45 On this as a prevalently polite act, see Denizot (2011: 468).

46 Brown and Levinson ( ${ }^{2} 1987$ ): positive politeness strategy 2 (pp. 106-108): 'Exaggerate (interest, approval, sympathy with $\mathrm{H}$ )' and negative politeness strategies 5 (178-187) 'Give deference', see esp. Brown and Levinson [ $\left.{ }^{2} 1987: 178\right]$ ) and 6 'Admit the impingement' (188189). From now on, strategies identified and page ranges will come from Brown and Levinson ( $\left.{ }^{2} 1987\right)$. 'S' refers to speaker; ' $\mathrm{H}$ ' to hearer.

47 Positive politeness strategy 14 'Assume or assert reciprocity' (129).

48 Positive politeness strategies 7 'Presuppose, raise, assert common ground' (117-124) and 14 'Assume or assert reciprocity' (129). Ar. Nub. 357.

49 Negative politeness strategy 4 'Minimize the imposition' (176-178).

$5^{\circ}$ Ar. Lys. 1188. Negative politeness strategy 2 'Don't assume H is willing/able' (145-172, esp. 162-163).

$5^{1} \quad$ Negative politeness strategy 2 'Don't assume $\mathrm{H}$ is willing/able' (145-172, esp. 162-163). 
(cont.)

\section{Type of softener / Politeness type Example phrase}

\begin{tabular}{|c|c|}
\hline $\begin{array}{l}\text { Out of respect or love for god, standards, } \\
\text { parents, etc. Negative Politeness. }{ }^{52}\end{array}$ & 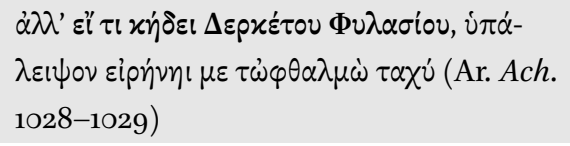 \\
\hline $\begin{array}{l}\text { Express wish of some benefit for A. Posit- } \\
\text { ive Politeness. }{ }^{53}\end{array}$ & 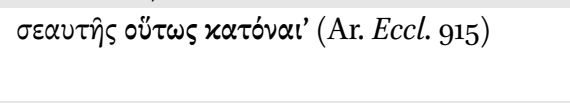 \\
\hline $\begin{array}{l}\text { Show that you take the A into consid- } \\
\text { eration in some way. Positive Polite- } \\
\text { ness. }{ }^{54}\end{array}$ & 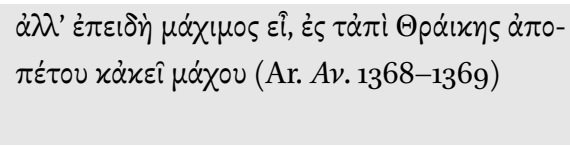 \\
\hline $\begin{array}{l}\text { Promise something to A. Positive Polite- } \\
\text { ness. }{ }^{55}\end{array}$ & 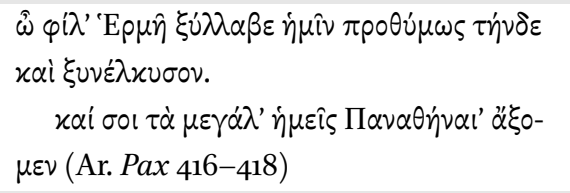 \\
\hline Vocatives PP & 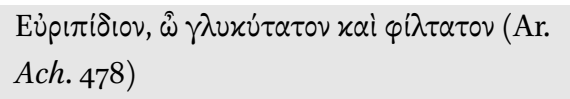 \\
\hline Vocatives NP & $\begin{array}{l}i \dot{\omega} \Lambda \alpha \dot{\alpha} \mu \alpha \chi^{\prime}, \hat{\omega} \beta \lambda \varepsilon \dot{\tau} \pi \omega \nu \dot{\alpha} \sigma \tau \rho \alpha \pi \alpha \dot{\varsigma} \text { (Ar. Ach. } \\
568)\end{array}$ \\
\hline
\end{tabular}

\section{References}

Arnott, W.G., (1979-200o), Menander, 3 vols., Cambridge, Mass./London.

Bakker, W.F., (1966), The Greek Imperative: an Investigation into the Aspectual Differences between the Present and Aorist Imperatives in Greek Prayer from Homer up to the Present Day, Amsterdam.

Barrios-Lech, P., (forthcoming), 'Towards a Comparison of Greek and Roman Politeness Systems', in Ł. Berger \& L. Unceta-Gómez (eds.), Approaches to Ancient Greek and Latin Im-/politeness.

$5^{2} \quad$ Negative politeness strategy 8 'State the imposition as a general rule' (206-207). Ar. Plut.

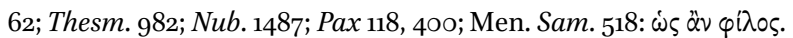

53 Positive politeness strategy 1 'Notice, attend to H. (his [sic.] interests, wants, needs, goods)' (103-104). Ar. Nub. 510.

54 Positive politeness strategy 9 'Assert or presuppose S's knowledge of and concern for H's wants' (125). Ar. Thesm. 763, Men. Dys. 41.

55 Positive politeness strategy 10 'Offer, promise' (125). 
Brown, P. \& Levinson, S.C., ( ${ }^{2} 1987$ [1978]), Politeness: some Universals in Language Usage, Cambridge.

Burnet, J., (1905), Platonis opera, vol. 1, Oxford.

Butler, C., (1985), Statistics in Linguistics, Oxford.

Cunningham, I.C., (1971), Herodas, Mimiambi, Oxford.

Cunningham, I.C., (2004), Herodas, Mimiambi, cum appendice fragmentorum mimorum papyraceorum, Munich/Leipzig.

Denizot, C., (forthcoming), 'How to Be Polite without Saying "Please" in Ancient Greek? The Role of $\delta \dot{\eta}$ in Polite Requests', in L. Unceta Gómez \& Ł. Berger (eds.), Im/politeness Research in Ancient Greek and Latin, Cambridge.

Denizot, C., (2011), Donner des ordres en grec ancien: étude linguistique des formes de l'injonction, Mont-Saint-Aignan.

Dickey, E., (1996), Greek Forms of Address: from Herodotus to Lucian, Oxford.

Dickey, E., (2001), 'Kúpıє, $\Delta \varepsilon \dot{\sigma} \tau о \tau \alpha$, Domine: Greek Politeness in the Roman Empire', Journal of Hellenic Studies 121, 1-11.

Dickey, E., (2009), 'Latin Influence and Greek Request Formula', in T.V. Evans \& D. Obbink (eds.), The Language of the Papyri, Oxford, 208-220.

Dickey, E., (2016a), 'Emotional Language and Formulae of Persuasion in Greek Papyrus Letters', in E. Sanders \& M. Johncock (eds.), Emotion and Persuasion in Classical Antiquity, Stuttgart, 237-262.

Dickey, E., (2016b), 'How the End of Democracy Made the Greeks more Polite', in Aeon, 10 August, 2016. https://aeon.co/ideas/how-the-end-of-democracy-made-the -greeks-more-polite [21/o6/2019].

Ferri, R., (2015), 'Graeca in Latin Texts and Other Emendations', Hermes 143, 503-507.

Kaster, R.A., (2005), Emotion, Restraint, and Community in Ancient Rome, Cary.

Labov, W., (1972), Sociolinguistic Patterns, Philadelphia.

Lloyd, M., (1999), 'The Tragic Aorist', Classical Quarterly 49, 24-45.

Lloyd, M., (2004), 'The Politeness of Achilles: Off-record Conversation Strategies in Homer and the Meaning of Kertomia', The Journal of Hellenic Studies 124, 7589 .

Márquez-Reiter, R., (200o), Linguistic Politeness in Britain and Uruguay: a Contrastive Study of Requests and Apologies, Amsterdam.

Olson, S.D., (2002), Aristophanes, Acharnians, Oxford.

Page, D.L., (1941), Select Papyri: Poetry III. Cambridge, Mass.

Schwyzer, E. \& Debrunner, A., (1966), Griechische Grammatik, Band 2: Syntax und Stilistik, Munich.

Sorrentino, G., (2013), Comunicazione e relazioni interpersonali nelle commedie di Menandro: un'indagine sul Dyscolos e sulla Samia, PhD thesis (University of Freiburg). https://freidok.uni-freiburg.de/fedora/objects/freidok:9582/datastreams/FILE1/ content [18/06/2019]. 
Unceta Gómez, L., (2009), La petición verbal en Latín: estudio léxico, semántico y pragmatico, Madrid.

Unceta Gómez, L., (2018), 'Gli studi sulla (s)cortesia linguistica in latino. Possibilità di analisi e proposte per il futuro', Studi e Saggi Linguistici 56(2), 9-37.

Wilson, N.G., (2007), Aristophanis fabulae, Oxford. 